\title{
Ro/SSA and La/SSB specific IgA autoantibodies in serum of patients with Sjögren's syndrome and systemic lupus erythematosus
}

\author{
Nader Pourmand, Marie Wahren-Herlenius, Iva Gunnarsson, Elisabet Svenungsson, \\ Björn Löfström, Yiannakis Ioannou, David A Isenberg, Carl G M Magnusson
}

\begin{abstract}
Objective-To investigate the occurrence of IgA autoantibodies to Ro $52 \mathrm{kDa}$, Ro 60 $\mathrm{kDa}$ and $\mathrm{La}$ antigen in serum of patients with primary Sjögren's syndrome (pSS) and systemic lupus erythematosus (SLE). Methods-Recombinant Ro 52 kDa, Ro 60 $\mathrm{kDa}$ and $\mathrm{La}$ antigens were used to analyse autoantibodies in serum from 25 patients with pSS, 30 patients with SLE and 20 controls using a semiquantitative immunoblotting approach.
\end{abstract}

Results-Among the patients with pSS, 21 (84\%) had detectable IgA autoantibodies to Ro $52 \mathrm{kDa}, 13(52 \%)$ to Ro $60 \mathrm{kDa}$ and 20 $(80 \%)$ to La antigen. The corresponding results for the patients with SLE were 22 $(73 \%), 14(47 \%)$ and $20(67 \%)$, respectively. No IgA autoantibodies against the three antigens were detected in 20 normal controls. A comparison of several clinical features with the titres of IgA antibodies to Ro $52 \mathrm{kDa}$, Ro $60 \mathrm{kDa}$ and La, revealed a significant relation between IgA anti-Ro 52 and IgA anti-La to sicca $(p<0.05)$. Semiquantitative data suggest that IgG is the dominating antibody to the three antigens followed by IgM > IgA in both SLE and pSS patients. Specificity studies of IgA autoantibodies with different subfragments of Ro $52 \mathrm{kDa}$ and Ro $60 \mathrm{kDa}$ antigens showed that IgA antibodies did not differ from IgG and IgM in their recognition pattern.

Conclusion-These results suggest that besides IgM and IgG, IgA autoantibodies are also detected at high frequency in patients with pSS and SLE. Further studies are necessary to evaluate the contribution of these IgA autoantibodies to inflammation as well as their diagnostic value.

(Ann Rheum Dis 1999;58:623-629)

The clinical relevance of measuring IgG and IgM autoantibodies to Ro/SSA and La/SSB has been established over the past 30 years. The Ro/SS-A autoantigen is a small intracellular RNA-protein complex. It consists of a 60 $\mathrm{kDa}$ protein associated with one of four RNAs of 83-112 bases, termed hY RNAs. ${ }^{12}$ This complex is at least transiently associated with the La polypeptide, ${ }^{2}$ which has been reported to take part in the maturation process of RNA polymerase III transcripts by binding to the uridine-rich 3 'ends. ${ }^{3-7}$ The association of a 52
$\mathrm{kDa}$ protein with the $\mathrm{Ro} / \mathrm{SS}-\mathrm{A}$ antigen was described later ${ }^{89}$ and it is thought to associate with the complex via the $60 \mathrm{kDa}$ protein. ${ }^{8} \mathrm{No}$ sequence homology exists between the $52 \mathrm{kDa}$ and $60 \mathrm{kDa}$ proteins. ${ }^{10-13}$ Whether the Ro 52 $\mathrm{kDa}$ protein is permanently associated with the Ro ribonucleoprotein or not, ${ }^{81415}$ and to which cellular compartment the Ro $52 \mathrm{kDa}$ protein is located, ${ }^{9}{ }^{16-18}$ are still unresolved questions.

IgG and IgM autoantibodies to these antigens have been detected in patients with primary or secondary Sjögrens syndrome (SS), systemic lupus erythematosus (SLE) and related disorders, and are now regarded as one of the hallmarks of these diseases. These antibodies are associated in particular with photosensitive rashes, subacute cutaneous lupus, neonatal lupus and congenital heart block, but their contribution to the pathogenesis of these diseases remains unclear. ${ }^{19} 20$

In contrast with the vast literature on $\mathrm{IgG}$ and $\operatorname{IgM}$ autoantibodies there are, to our knowledge, only a few studies on Ro/SSA and La/SSB-specific IgA autoantibodies. ${ }^{21-23}$ Previously, total serum IgA concentrations have been reported to be high in patients with SS and SLE but no correlation with clinical features has been established. ${ }^{24-26}$

The aim of this report was to study $\operatorname{IgA}$ autoantibodies to Ro $52 \mathrm{kDa}$, Ro $60 \mathrm{kDa}$ and La in serum of patients with pSS and SLE. A semiquantitative immunoblotting approach permitted comparison of the IgA results to clinical features, as well as to the specificity and levels of IgG and IgM.

\section{Methods}

PATIENT AND CONTROL SERA

Sera from 25 patients $(24 \mathrm{~F} / 1 \mathrm{M}$; median age 64 ; range 29-86 years) who met the European criteria for primary Sjögren's syndrome $(\mathrm{pSS})^{27}$ were supplied by the Centre for Rheumatology/ Bloomsbury Rheumatology Unit, Department of Medicine, University College London, England. Thirty sera from patients with SLE who had four or more of the revised criteria of the American College of Rheumatology (ACR), ${ }^{28}$ (27 F/3 M; median age 52; range $22-82$ years) were obtained from the Department of Medicine, Rheumatology Unit, Karolinska Hospital, Stockholm, Sweden. All 55 patient sera were Ro/SSA and La/SSB positive by immunodiffusion or counter immunoelectrophoresis. Clinical and serological features typical of SLE and pSS were recorded. These included dermal manifestations, serositis, nephritis, arthritis, 
A

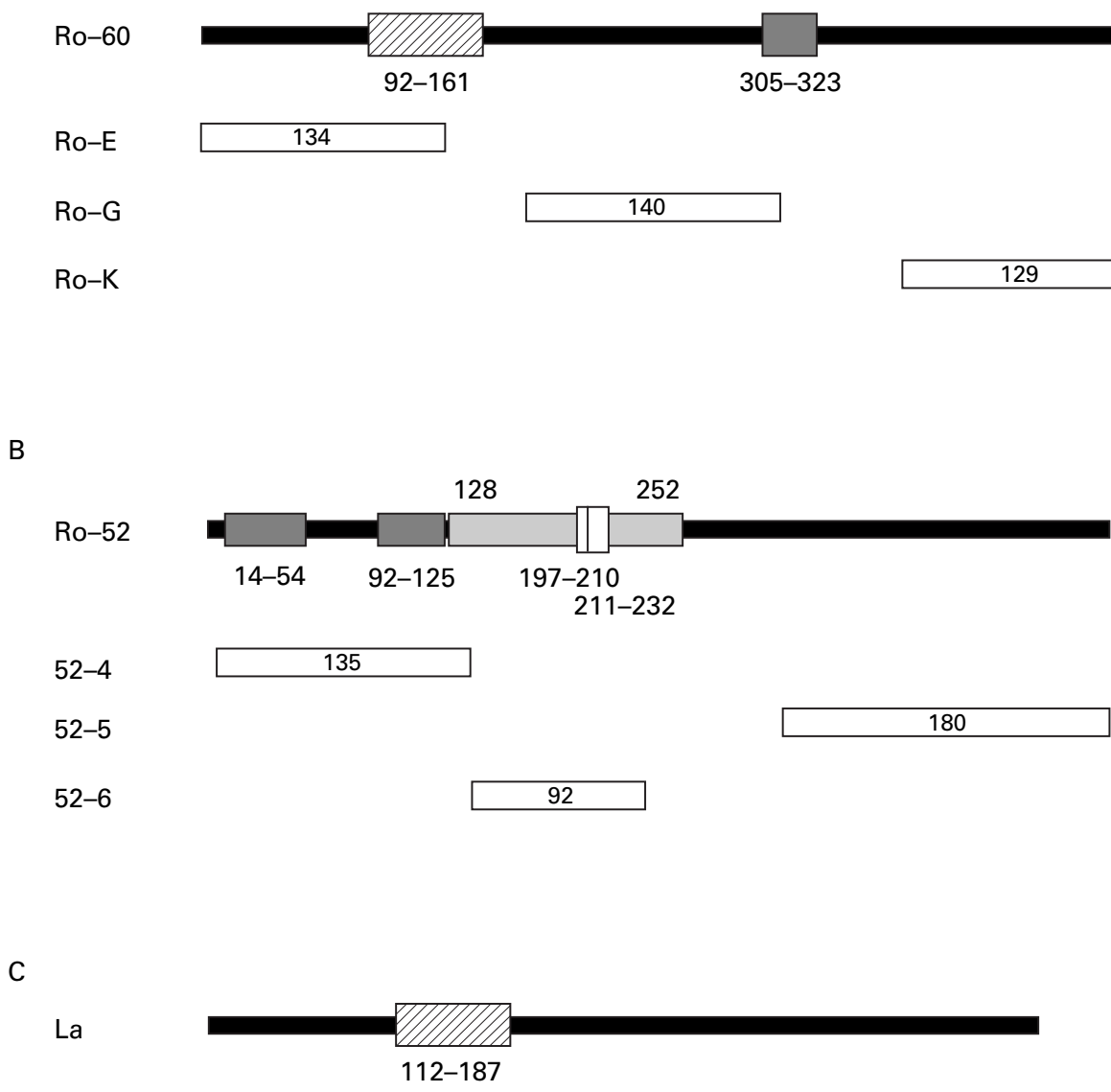

Figure 1 Schematic representation of Ro $60 \mathrm{kDa}$, Ro $52 \mathrm{kDa}$ and La proteins. The hatched boxes indicate the position of $R N A$ binding domains, the dark grey boxes indicate the position of Cys/His clusters and the grey box represents the hydrophilic putative alpha-helical region with an incomplete and a complete leucin zipper indicated by open boxes. Amino acid positions are indicated by numbers. The number of amino acid residues encoded by each clone is indicated inside the corresponding open bar. The position of the clones relative to the deduced Ro $52 \mathrm{kDa}$, Ro $60 \mathrm{kDa}$ and La amino acid sequence is indicated to the right. (A) Ro $60 \mathrm{kDa}$ protein and three subclones. (B) Ro $52 \mathrm{kDa}$ protein and three subclones. (C) La protein.

CNS symptoms, haematological manifestations, sicca symptoms (defined as severe and continuous problems with dryness in mouth and eyes. In most cases, the diagnosis was also confirmed by measurements of salivation and Schirmers test), and rheumatoid factor (RF). In the SLE patients, secondary Sjögren's syndrome was determined by noting the relevant clinical history and demonstrating objective dryness of both eyes and mouth. All sera were stored at $-70^{\circ} \mathrm{C}$ until use. As controls, sera from 20 randomly selected healthy blood donors were used.

EXPRESSION AND PREPARATION OF RECOMBINANT PROTEINS

cDNA clones of Ro 52 kDa, Ro 60 kDa, La 48 $\mathrm{kDa}$ and a set of subclones were expressed with maltose binding protein (MaBP) as fusion partner in Escherichia coli TB1 strain in the pMAL vector system (New England Biolabs, Beverly, MA, USA) as described previously. ${ }^{29-31}$ Figure 1 illustrates the constructs used in this paper.

Expression of recombinant proteins was induced by $0.3 \mathrm{mM}$ isopropyl- $\beta-\mathrm{D}$ thiogalactoside at $37^{\circ} \mathrm{C}$ for two hours. Bacteria from induced cultures were spun down and pellets frozen at $-70^{\circ} \mathrm{C}$ overnight. After thawing for 30 minutes, addition of Triton
$\mathrm{X}-100$ to $0.1 \%$ and incubation for another 10 minutes, the pellets were sonicated six times for 10 seconds with a Branson sonifier (Optilab, Stockholm, Sweden) at setting 4. After centrifugation for 15 minutes at $12000 \mathrm{~g}$, supernatants were used as the source of soluble antigens following purification on an amylose column according to the manufacturer's instructions (New England Biolabs). Protein concentrations were determined with the Bio-Rad Protein-assay (Bio-Rad Sundbyberg, Sweden) using BSA as standard. Insoluble full length Ro $60 \mathrm{kDa}$ fusion protein, pelleted after the sonication step was first extracted with $1 \mathrm{M}$ urea and thereafter with $6 \mathrm{M}$ urea. The $6 \mathrm{M}$ urea preparation was used as antigen source in immunoblotting.

\section{ABSORBTION PROCEDURE}

An excess of protein G Sepharose 4 Fast Flow (Pharmacia Biotech, Uppsala, Sweden) was used to deplete IgG from the serum samples for subsequent IgA and $\operatorname{IgM}$ antibody detection. Protein $G$ is known to react with all four human IgG subclasses but neither with human IgA nor human IgM. ${ }^{32}$ Three volumes of protein G Sepharose ( $50 \%$ suspension) and one volume of serum were mixed, and PBS-TW (phosphate buffered saline containing $0.05 \%$ Tween $20, \mathrm{pH} 7.4$ ) added to the 


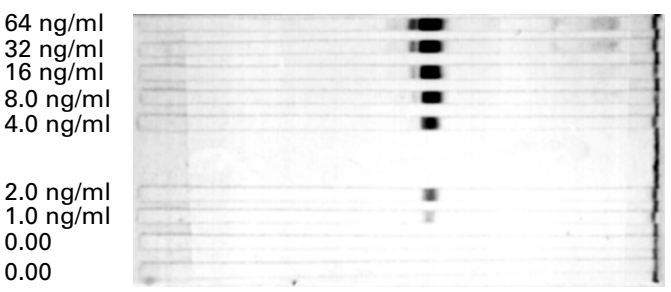

Figure 2 Illustration of the use of chimeric IgA anti-NIP antibodies to semiquantify immunoblotting data. BSA-NIP conjugate was separated on SDS-PAGE and transferred to a blotting membrane. After incubation with different concentrations of IgA anti-NIP antibodies $(0-64 \mathrm{ng} / \mathrm{ml})$ the membrane was incubated with anti-IgA enzyme conjugate and developed with BCIP/NBT for 30 minutes.

mixture to reach a final serum dilution of 1:100. After one hour incubation end over end at room temperature, the mix was centrifuged (30 sec; >3000 g) and the IgG depleted supernatant carefully withdrawn and finally diluted 1:250 before IgA and IgM antibody analysis by immunoblotting. IgG antibodies were tested at 1:2000 dilution of serum without prior incubation with protein G Sepharose.

The efficacy of the absorption procedure was verified by comparing the serum $\operatorname{IgG}, \operatorname{IgA}$ and IgM concentrations before and after protein $G$ incubation by nephelometry (Beckman-array, Beckman, USA).

IMMUNOBLOTTING

Affinity purified recombinant proteins were run by SDS-PAGE on homogeneous $10 \%$ gels under reducing conditions ${ }^{29}$ and thereafter transferred electrophoretically to $0.2 \mu \mathrm{m}$ nitrocellulose membranes (Protran, Dassel, Germany). The membranes were washed twice

Table 1 Frequency of detectable antigen specific IgG, IgM and IgA autoantibodies in patients with SLE $(n=30), p S S$ $(n=25)$ and normal controls $(n=20)$ by immunoblotting

\begin{tabular}{lllll}
\hline Antigen & Ig Class & Control (\%) & SLE n (\%) & pSS n (\%) \\
\hline Ro 52 & IgG & 0 & $24(80)$ & $21(84)$ \\
& IgM & 0 & $21(70)$ & $19(76)$ \\
\multirow{4}{*}{ Ro 60 } & IgA & 0 & $22(73)$ & $21(84)$ \\
& IgG & 0 & $16(53)$ & $14(56)$ \\
& IgM & 0 & $7(23)$ & $6(24)$ \\
La & IgA & 0 & $14(47)$ & $13(52)$ \\
& IgG & 0 & $21(70)$ & $20(80)$ \\
& IgM & 0 & $20(67)$ & $19(76)$ \\
MaBP & IgA & 0 & $20(67)$ & $20(80)$ \\
& IgG & 0 & 0 & 0 \\
& IgM & 0 & 0 & 0 \\
& IgA & 0 & 0 & 0
\end{tabular}

MaBP (Maltose binding protein) is the fusion partner for the recombinant antigens.
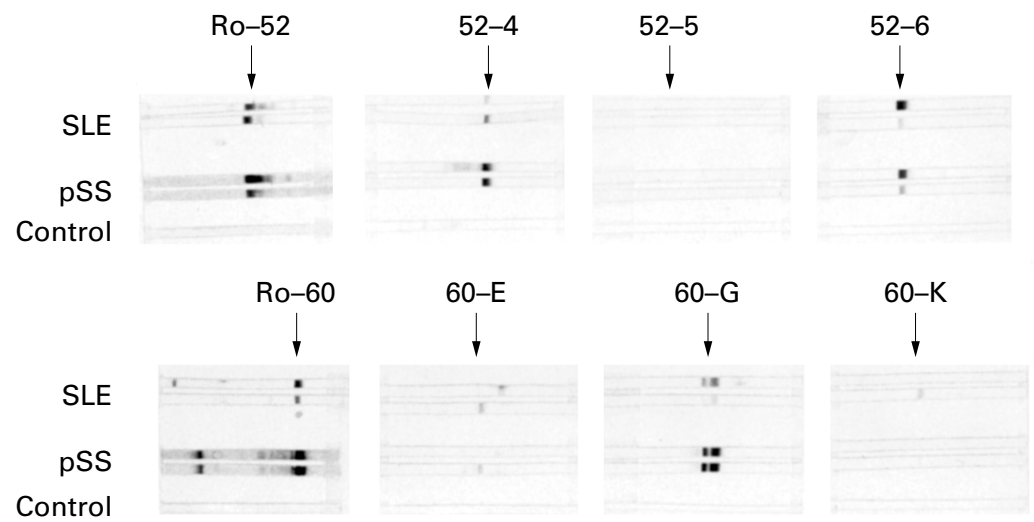

Figure 3 Representative recognition pattern of $\operatorname{Ig} A$ anti-Ro $52 \mathrm{kDa}$ and anti-Ro $60 \mathrm{kDa}$ antibodies to six subfragments in two patients with SLE, two with $p S S$ and one control. with PBS-TW and incubated for 15 minutes at room temperature with PBS-TW containing $2 \%$ bovine serum albumin (BSA) and $4 \%$ milk powder to block non-specific binding sites. Membranes were washed three times with PBS-TW and cut into $1.0-1.5 \mathrm{~mm}$ wide strips and incubated in eight well trays with diluted patient serum or with sera that had been pre-incubated with protein G Sepharose for two hours. The strips were washed four times with PBS-TW before addition of rabbit antihuman anti-IgA (1:500) or antihuman anti-IgM $(1: 1200)$ antibodies in the form of alkaline phosphatase-conjugated $\mathrm{F}\left(\mathrm{ab}^{\prime}\right)_{2}{ }^{-}$ fragments. After incubation for three hours at room temperature, and four washes, the strips were developed for 30 minutes with Nitro Blue Tetrazolium/5-Bromo-4-Chloro-3Indolyl Phosphate, (Sigma, St Louis, MO, USA). IgG antibodies were similarly detected with alkaline phosphatase conjugated rabbit antihuman IgG antibodies (Dakopatts AB, Stockholm, Sweden) at a 1:2000 dilution. All samples, standards and conjugates were diluted in PBS-TW containing $0.2 \%$ BSA and $0.4 \%$ milk powder.

IGA, IGG- AND IGM-ANTI-NIP

Supernatants containing calibrated concentrations of chimeric IgA1, IgG1 and IgM anti-NIP (5-iodo-4-hydroxy-3-nitrophenacetyl) antibodies were used to semiquantify the blotting results. The chimeric antibodies consist of the same mouse light chain and a heavy chain assembled from different human isotype constant regions each joined to the same mouse variable region specific for NIP. ${ }^{33}$ BSA-NIP conjugates $(1 \mathrm{mg} / \mathrm{ml} ; 8 \mu \mathrm{l} / \mathrm{gel})$ prepared according to Michaelsen et $a l^{34}$ was separated by SDS-PAGE, electroblotted and tested with different concentrations of anti-NIP antibodies in parallel to the detection of autoantibodies. In this way, it was possible to obtain a semiquantitative estimation of the concentration of autoantibodies and it also offered the possibility to compare strips from different experiments.

STATISTICAL ANALYSIS

Pearson's $\chi^{2}$ test was used to analyse the semiquantitative data of Ro $52 \mathrm{kDa}$, Ro $60 \mathrm{kDa}$ and La $48 \mathrm{kDa}$ autoantibodies in relation to clinical data. A p value $<0.05$ was considered significant.

\section{Results}

SEMIQUANTITATIVE DETECTION OF ANTIBODIES Serial dilutions of the chimeric anti-NIP antibodies were used to verify the sensitivity of the immunoblotting method. The detection limits for $\operatorname{IgA}, \operatorname{IgG}$ and $\operatorname{IgM}$ were 1,1 and 6 $\mathrm{ng} / \mathrm{ml}$, respectively, which after multiplication with the dilution factors correspond to a sensitivity in serum of $0.25,2.0$ and $1.5 \mu \mathrm{g} / \mathrm{ml}$, respectively. An example of this semiquantitative procedure is illustrated for IgA anti-NIP (fig 2) and it was used to divide the autoantibody levels into four groups according to the following ranges: for IgG $<2.0 \mu \mathrm{g} / \mathrm{ml}$ $(-), 2.0-4.0 \mu \mathrm{g} / \mathrm{ml}(+), 4.0-8.0 \mu \mathrm{g} / \mathrm{ml}(++)$ and 

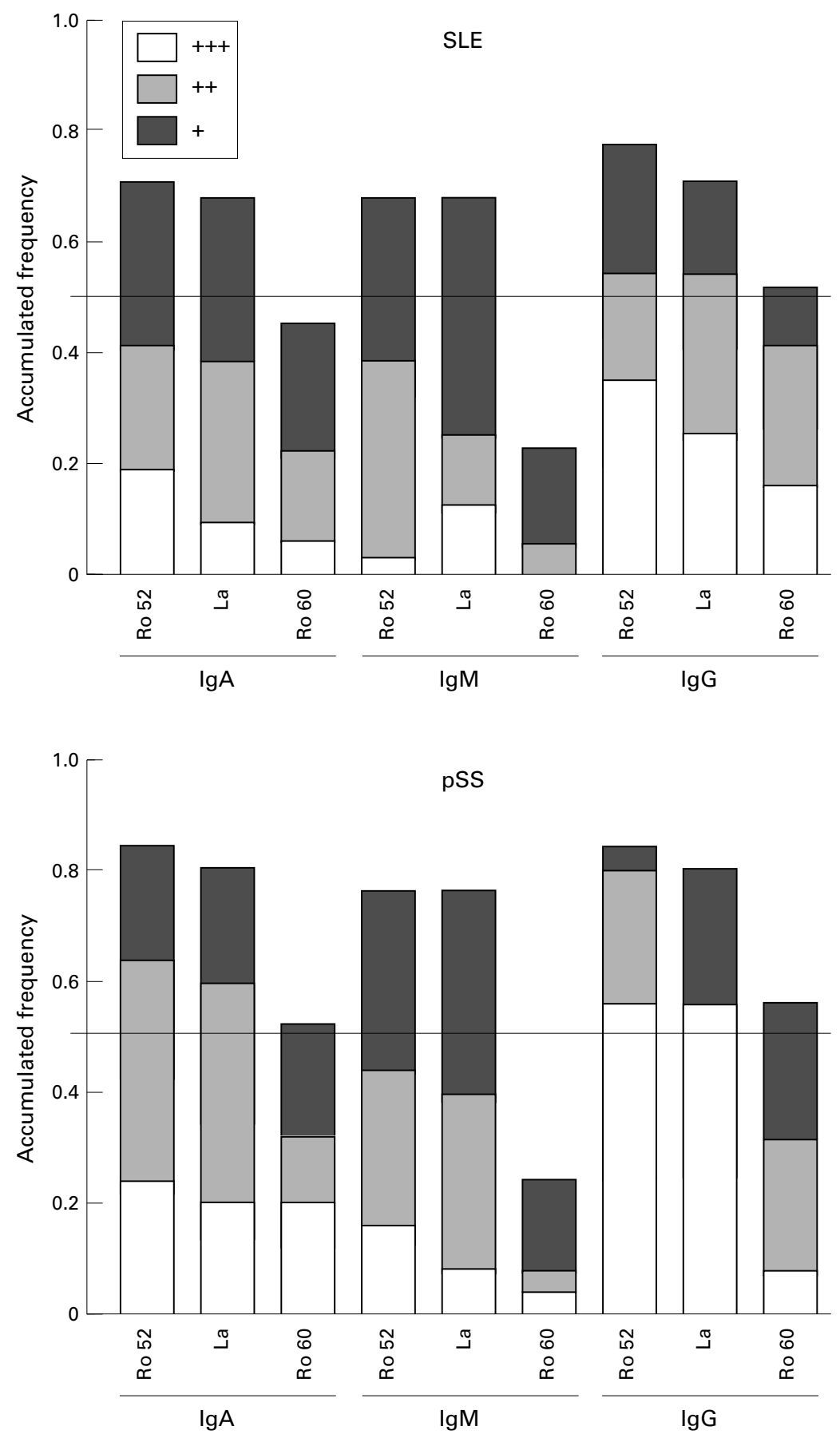

Figure 4 Frequency of serum IgG, IgA and IgM autoantibodies to Ro $60 \mathrm{kDa}$, Ro 52 $k D a$ and La proteins in pSS and SLE patients by immunoblotting. The intensity of the signal in immunoblotting was semiquantified in relation to serial dilutions of chimeric anti-NIP antibody results. The following groups were established; for Ig $A 0.25-0.5 \mu \mathrm{g} / \mathrm{ml}$ (+), $0.5-1.0 \mu \mathrm{g} / \mathrm{ml}(++)$ and $>1.0 \mu \mathrm{g} / \mathrm{ml}(+++)$; for IgM 1.50-3.0 $\mu \mathrm{g} / \mathrm{ml}(+), 3.0-6.0$ $\mu \mathrm{g} / \mathrm{ml}(++)$ and $>6.0 \mu \mathrm{g} / \mathrm{ml}(+++)$; for $\mathrm{IgG} 2.0-4.0 \mu \mathrm{g} / \mathrm{ml}(+), 4.0-8.0 \mu \mathrm{g} / \mathrm{ml}(++)$ and $>8.0 \mu \mathrm{g} / \mathrm{ml}(+++)$. The horizontal lines indicates median values.

$>8.0 \mu \mathrm{g} / \mathrm{ml}(+++)$; for $\operatorname{Ig} M<1.5 \mu \mathrm{g} / \mathrm{ml}(-)$, $1.5-3.0 \mu \mathrm{g} / \mathrm{ml}(+), 3.0-6.0 \mu \mathrm{g} / \mathrm{ml}(++)$ and $>$ $6.0 \mu \mathrm{g} / \mathrm{ml}(+++)$; for $\operatorname{IgA}<0.25 \mu \mathrm{g} / \mathrm{ml}(-)$, $0.25-0.5 \mu \mathrm{g} / \mathrm{ml}(+), 0.5-1.0 \mu \mathrm{g} / \mathrm{ml}(++)$ and $>$ $1.0 \mu \mathrm{g} / \mathrm{ml}(+++)$.

ANTIGEN SPECIFIC IGA, IGG AND IGM AUTOANTIBODIES

To minimise competition from antigen specific IgG autoantibodies and various non-specific interactions, IgG was depleted from the sera before the analysis of antigen specific IgA or IgM autoantibodies. A pilot experiment was performed to verify the efficiency of the IgG depletion procedure in two sera containing 9.3, 3.2 and $1.1 \mathrm{~g} / 1$; and $10.4,4.3$ and $1.1 \mathrm{~g} / \mathrm{lof} \mathrm{IgG}$, IgA and IgM, respectively. The concentrations of $\operatorname{IgG}, \operatorname{IgA}$ and $\operatorname{IgM}$ were measured at a 10-fold dilution by nephelometry before and after protein $G$ treatment. The results show that $>98 \%$ of the IgG was depleted in both sera whereas $\operatorname{IgA}$ and $\operatorname{IgM}$ were not affected at all $(<2 \%)$.

In the 30 SLE patients IgA autoantibodies to Ro $52 \mathrm{kDa}$, Ro $60 \mathrm{kDa}$ and $\mathrm{La} 48 \mathrm{kDa}$ were detected in $73 \%, 47 \%$ and $67 \%$ of the patients respectively (table 1). Similar but slightly higher frequencies were obtained in the $25 \mathrm{pSS}$ patients for whom the corresponding figures were $84 \%, 52 \%$ and $80 \%$, respectively. Figure 3 shows the representative immunoblotting results for IgA autoantibodies to Ro $52 \mathrm{kDa}$ and Ro $60 \mathrm{kDa}$.

The frequency of detectable IgG and IgM autoantibodies to the three antigens was similar to those obtained for IgA in both patient groups (table 1). The only difference was a lower frequency of IgM anti-Ro $60 \mathrm{kDa}$ antibodies compared with those of $\operatorname{IgA}$ and IgG in both SLE and pSS patients (table 1).

No IgA, IgG or IgM autoantibodies to Ro 52 $\mathrm{kDa}$, Ro $60 \mathrm{kDa}$ and La/SSB were detected in the 20 sera of the control group. Moreover, there were no reactions to the wild type $\mathrm{MaBP}$-fusion protein in any of the sera from the patient or healthy control groups (data not shown).

The semiquantitative procedure was used to divide the results into four groups and allowed comparison of autoantibody levels of the three classes of immunoglobulins (fig 4). The median serum levels in the SLE and pSS patients were calculated and showed that IgG autoantibodies dominated in concentration followed by $\operatorname{Ig} M>\operatorname{IgA}$. The same pattern was seen for both patient groups and for all three antigens (fig 4).

A comparison of the number of patients having various combinations of detectable $\operatorname{IgA}$, IgG and $\operatorname{IgM}$ autoantibodies is illustrated in table 2. As shown most SLE patients were both IgG and IgM positive to Ro $52 \mathrm{kDa}(63 \%)$ and La $(60 \%)$. IgG was most common among patients with either IgG or IgM positivity whereas 13\% (Ro $52 \mathrm{kDa}$ ) and 20\% (La) were both IgG and IgM negative. For Ro $60 \mathrm{kDa}$ the figures were the other way around and most patients were both $\operatorname{IgG}$ and $\operatorname{IgM}$ negative (43\%) with only $20 \%$ being both IgG and IgM positive. The corresponding calculations for pSS patients gave very similar results (table 2).

The probability of having an IgA response in $\operatorname{IgG} / \operatorname{IgM}$ positive patients was near $100 \%$ for both patient groups and towards all three antigens (table 2). A decline in this probability among patients being either $\operatorname{IgG}$ or $\operatorname{IgM}$ positive was observed mainly for patients with SLE. Finally, an exclusive IgA response was recorded in two patients with SLE who both had a weak $1+$ reactivity against Ro $60 \mathrm{kDa}$.

\section{EPITOPE RECOGNITION}

A representative group of serum samples having $\operatorname{IgA}, \operatorname{IgG}$ or $\operatorname{IgM}$ autoantibodies to 
Table 2 Number of patients with SLE and pSS having various combinations of detectable $\operatorname{Ig} A, \operatorname{Ig} G$ and IgM autoantibodies

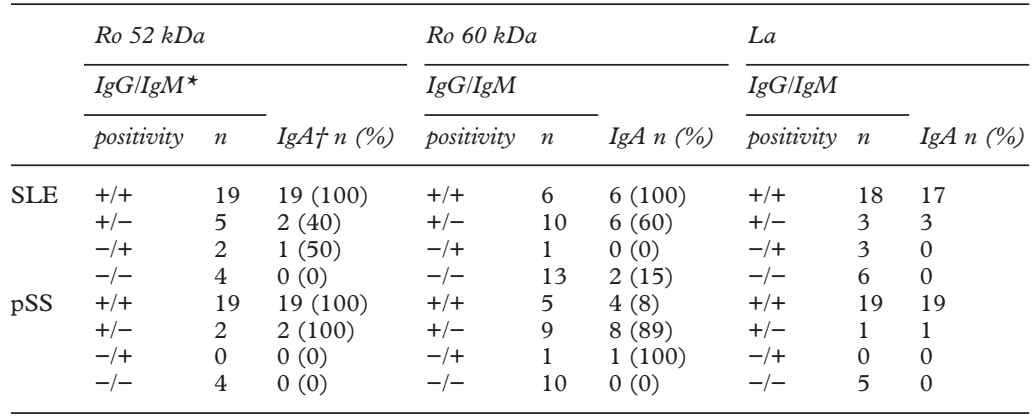

$\star$ Indicates the number of patients (n) with detectable levels of IgG and/or IgM autoantibodies (that is, $\geqslant 1+$ reactivity in immunoblotting). +Indicates the number of patients (n) with detectable IgA autoantibodies.

Table 3 Epitope recognition of $\operatorname{Ig} G, \operatorname{Ig} M$ and $\operatorname{Ig} A$ autoantibodies to different subfragments * of the Ro $52 \mathrm{kDa}$ and Ro $60 \mathrm{kDa}$ proteins

\begin{tabular}{llllllllll}
\hline & & $\begin{array}{l}\text { Ro } 52 \\
n \dagger\end{array}$ & $\begin{array}{l}52-4 \\
n(\%)\end{array}$ & $\begin{array}{l}52-5 \\
n(\%)\end{array}$ & $\begin{array}{l}52-6 \\
n(\%)\end{array}$ & $\begin{array}{l}\text { Ro } 60 \\
n\end{array}$ & $\begin{array}{l}60-E \\
n(\%)\end{array}$ & $\begin{array}{l}60-G \\
n(\%)\end{array}$ & $\begin{array}{l}60-K \\
n(\%)\end{array}$ \\
\hline SLE & IgG & 8 & $6(75)$ & 0 & $6(75)$ & 6 & $1(17)$ & $6(100)$ & 0 \\
& IgM & 7 & $1(14)$ & 0 & $2(29)$ & 2 & 0 & $1(50)$ & 0 \\
& IgA & 8 & $4(50)$ & 0 & $6(75)$ & 7 & $1(14)$ & $4(57)$ & $1(14)$ \\
\multirow{4}{*}{ pSS } & IgG & 8 & $8(100)$ & 0 & $8(100)$ & 6 & $2(33)$ & $6(100)$ & $3(50)$ \\
& IgM & 8 & $4(50)$ & 0 & $6(75)$ & 6 & 0 & $3(50)$ & 0 \\
& IgA & 8 & $6(75)$ & 0 & $7(88)$ & 6 & $3(50)$ & $4(67)$ & 0
\end{tabular}

*The subfragments are illustrated in figure 1 . $†$ Number of patients with positive immunoblotting to full length Ro $52 \mathrm{kDa}$ and Ro $60 \mathrm{kDa}$, and their subfragments, respectively.

recombinant Ro $52 \mathrm{kDa}$ and $\mathrm{Ro} 60 \mathrm{kDa}$ proteins were selected for epitope studies. Thus, eight sera from patients with pSS, eight sera from patients with SLE and six sera from the control group were tested against three recombinant subfragments of Ro 52 ( 52-4, $52-5,52-6)$ and three subfragments of Ro 60 (60-E, 60-G, 60-K) (fig 1). The reactivity pattern of IgA autoantibodies was similar to those observed for IgG and IgM in both groups of patients, except for one SLE patient who had a clear IgA reactivity against the C-terminal part of Ro $60 \mathrm{kDa}$ protein (table 3 and fig 3). All six control sera were negative to all subfragments.

\section{CLINICAL CORRELATION TO SPECIFIC}

AUTOANTIBODIES

The semiquantitative data of IgA autoantibodies to Ro $52 \mathrm{kDa}$, Ro $60 \mathrm{kDa}$ and La $48 \mathrm{kDa}$ were compared with several clinical and serological features of pSS and SLE patients (table 4). Significant but weak correlations were found between sicca (defined as keratoconjunctivitis and an inflamed salivary gland) and $\operatorname{IgA}$ antibodies to Ro $52 \mathrm{kDa}(\mathrm{p}=0.032)$ and $\mathrm{La} / \mathrm{SSB}(\mathrm{p}=0.029)$. Similarly, weak correlations were obtained for IgG $(p<0.05)$ but not for IgM. No correlations between anti-Ro 60 $\mathrm{kDa}$ antibodies and any clinical parameters were noted.

\section{Discussion}

In this study, serum $\operatorname{IgA}, \operatorname{Ig} M$ and IgG anti-Ro $52 \mathrm{kDa}$, anti-Ro $60 \mathrm{kDa}$ and anti-La autoantibodies were analysed and compared in patients with pSS and SLE by a semi-quantitative immunoblotting procedure. IgA autoantibodies to Ro $52 \mathrm{kDa}$, Ro $60 \mathrm{kDa}$ and $\mathrm{La}$ antigen were found at a high frequency (47-84\%) in the serum of patients with pSS and SLE. Although, IgG and to a lesser extent IgM, anti-Ro $52 \mathrm{kDa}$, anti-Ro $60 \mathrm{kDa}$ and anti-La antibodies have been extensively studied, ${ }^{29} 313536$ to our knowledge there are only a few studies on IgA antibodies with these specificities in patients with SS and none in patients with SLE. IgA anti-La antibodies have been demonstrated in serum and saliva from patients with $\mathrm{SS}^{21}$ and quite recently the production of $\operatorname{IgA}$ antibodies to all three antigens was demonstrated in the salivary glands and serum of a few patients with $\mathrm{SS}^{22}$ In contrast a high total serum $\operatorname{IgA}$ concentration is commonly seen in both SS and SLE patients. ${ }^{24-26} 37$

Previous studies have indicated that some patients diagnosed with SLE and SS and who are $\mathrm{Ro} / \mathrm{La}$ positive by immunodiffusion or counter immunoelectrophoresis have undetectable antibody levels by ELISA and immunoblotting. ${ }^{38} 39$ These differences may be related to a variability in epitope/antigen characteristics in various techniques. Antigens or epitopes may be lacking and/or be susceptible to immobilisation and sample treatments. Our results suggest that these technique related discrepancies cannot be explained by $\operatorname{IgA}$ as nearly all patients negative for $\operatorname{IgG}$ and $\operatorname{IgM}$ antibodies also were IgA negative.

Epitope studies with subfragments of Ro 52 $\mathrm{kDa}$ and Ro $60 \mathrm{kDa}$ have previously shown that IgG antibodies react mainly with the N-terminal and middle parts of the antigen..$^{29} 3036$ Our results indicate that IgA as well as IgM autoantibodies follow the same reactivity pattern suggesting common immunodominant regions for these three classes of immunoglobulins. Interestingly one SLE

Table 4 Clinical symptoms and IgA antibody repertoire to Ro 52, Ro 60 and La antigens in patients with pSS ( $n=25)$ and SLE ( $n=30$ )

\begin{tabular}{|c|c|c|c|c|c|c|c|c|c|c|c|}
\hline $\begin{array}{l}\text { Immunoblot } \\
\text { reactivity }\end{array}$ & $\begin{array}{l}\text { Patients } \\
(n)^{\star}\end{array}$ & Diagnosis & $R F$ & $\begin{array}{l}\text { Dermal } \\
\text { manifestations }\end{array}$ & Serositis & Nephritis & Arthritis & $\begin{array}{l}\text { Haematological } \\
\text { manifestations }\end{array}$ & CNS & $\begin{array}{l}\text { Sicca } \\
\text { oral }\end{array}$ & $\begin{array}{l}\text { Sicca } \\
\text { occular }\end{array}$ \\
\hline Ro $52+60+\mathrm{La}$ & 13 & $\mathrm{pSS}$ & 10 & 5 & 0 & 1 & 8 & 2 & 1 & 13 & 13 \\
\hline Ro $52+\mathrm{La}$ & 7 & pSS & 5 & 3 & 0 & 2 & 2 & 3 & 0 & 7 & 7 \\
\hline Ro $52+60$ & 0 & pSS & 0 & 0 & 0 & 0 & 0 & 0 & 0 & 0 & 0 \\
\hline Ro 52 only & 1 & pSS & 0 & 0 & 0 & 0 & 1 & 0 & 0 & 1 & 1 \\
\hline Ro 60 only & 0 & pSS & 0 & 0 & 0 & 0 & 0 & 0 & 0 & 0 & 0 \\
\hline La only & 0 & pSS & 0 & 0 & 0 & 0 & 0 & 0 & 0 & 0 & 0 \\
\hline No reaction & 4 & pSS & 3 & 1 & 0 & 0 & 4 & 2 & 0 & 4 & 4 \\
\hline Ro $52+60+\mathrm{La}$ & 11 & SLE & 4 & 10 & 7 & 3 & 9 & 6 & 3 & 5 & 6 \\
\hline Ro $52+\mathrm{La}$ & 8 & SLE & 3 & 7 & 6 & 1 & 6 & 5 & 2 & 1 & 1 \\
\hline Ro $52+60$ & 2 & SLE & 0 & 2 & 0 & 1 & 1 & 2 & 1 & 2 & 2 \\
\hline Ro 52 only & 1 & SLE & 0 & 1 & 1 & 1 & 1 & 0 & 0 & 1 & 0 \\
\hline Ro 60 only & 1 & SLE & 0 & 1 & 0 & 0 & 0 & 1 & 0 & 0 & 1 \\
\hline La only & 2 & SLE & 0 & 2 & 1 & 1 & 1 & 0 & 2 & 2 & 1 \\
\hline No reaction & 5 & SLE & 0 & 4 & 3 & 0 & 3 & 2 & 1 & 1 & 2 \\
\hline
\end{tabular}

^Number of patients with a positive immunoblot $(\geqslant 1+$ reaction). 
patient reacted with the C-terminal part of Ro $60 \mathrm{kDa}$ a specificity equally uncommon among IgG and IgM antibodies. Moreover, two SLE patients had an exclusive IgA response against Ro $60 \mathrm{kDa}$ and we observed a lower frequency of IgM anti-Ro $60 \mathrm{kDa}$ antibodies as compared with those of IgG and IgA in both SLE and pSS patients. The reasons for these findings are unclear but they might bear on differences in antibody affinity and/or epitope conformation. The physiological and diagnostic implications of these different specificities need further studies.

$\operatorname{Ig} \mathrm{A}$ is the main isotype produced locally by the mucosal tissue. Mucosal antibodies are functionally important to protect against viruses and bacteria in both mucosal and systemic compartments. ${ }^{40}$ The molecular size of IgA antibodies may influence their biological effects. Polymeric IgA, which is present in plasma, is able to activate the alternative pathway of the complement system. ${ }^{41}$ Polymeric IgA binds stronger to cellular receptors and is therefore more effective than monomeric $\operatorname{IgA} .{ }^{42}$ This suggests that polymeric IgA autoantibodies might be more effective in inducing tissue damage than monomeric IgA. However, we presently do not know the IgA subclass or polymeric forms of the observed IgA autoantibodies. IgA immunoglobulin have been found deposited in the glomeruli of SLE patients with nephritis. ${ }^{43}{ }^{44}$ It would be interesting to determine if Ro $52 \mathrm{kDa}, 60 \mathrm{kDa}$ and $\mathrm{La}$ antigen participate in such IgA complexes.

Measurements of antigen specific autoantibodies in serum of patients with autoimmune disease by various immunoassays may give erroneous results for different reasons. Besides background caused by non-specific binding to the solid phase class specific rheumatoid factors commonly found in SLE and SS $\operatorname{sera}^{45}{ }^{46}$ may either directly react with unspecific or specific IgG, or they may capture enzyme conjugates of IgG type. To minimise these drawbacks we used an efficient blocking buffer, IgG depleted serum and enzyme conjugates in the form of $\mathrm{F}\left(\mathrm{ab}^{\prime}\right)_{2}$ fragments. We also used chimeric antibodies to evaluate the sensivity and improve on the comparison between immunoblotting experiments. This attempt to semiquantify the antibody concentrations demonstrated that $\operatorname{IgG}$ dominates the autoantibody response in both SLE and pSS with a similar median concentration in serum of $5-8 \mu \mathrm{g} / \mathrm{ml}$ against all tested antigens. The corresponding median concentrations for $\operatorname{IgM}$ $(2-3 \mu \mathrm{g} / \mathrm{ml})$ and $\operatorname{IgA}(0.5-1.0 \mu \mathrm{g} / \mathrm{ml})$ were slightly lower. Still, the relatively high concentration of $\operatorname{IgA}$ antibodies suggests physiological implications.

We are unaware of any previous attempts to correlate IgA anti-Ro/SSA and anti-La/SSB autoantibodies to clinical features in patients with pSS or SLE. However, we were unable to find any major link to any particular clinical feature besides a weak correlation between sicca symptoms, and the presence of $\operatorname{IgA}$ anti-Ro $52 \mathrm{kDa}$, and IgA anti-La, respectively.

In conclusion, we have demonstrated a high frequency of IgA anti-Ro/SSA and anti-La/SSB autoantibodies in serum of patients with pSS and SLE. Our semiquantitative immunoblotting approach suggests that IgG dominates the autoantibody response followed by $\operatorname{Ig} M>\operatorname{IgA}$. The epitope specificity of the IgA autoantibodies closely followed that of $\operatorname{IgG}$ and $\operatorname{IgM}$. The diagnostic and physiological relevance of IgA autoantibodies in SS and SLE need further evaluation.

We gratefully acknowledge Mrs Evi Mellquist and Mrs Maggy Magnusson for outstanding technical assistance.

Funding: research support for this study was provided by the Swedish Society for Medicine; the Royal Swedish Academy of Sciences; The Swedish foundation of Health Care Sciences and Allergy Research; Karolinska Institutet; Jubileum Foundation of Disease Insurance; the Swedish Rheumatism Association; the Swedish Medical Research Concil; the Swedish Foundation for Strategic Reseach; the Royal Swedish Academy of Sciences; the Tornspiran, Hesselman and Consul Th C Bergh; the LundTornspiran, Hesselman and Consul Th C Bergh; the Lundström, the Magn. Bergvall, Professor Nanna Svartz', King Gustaf V:s 80 -year, Ake
Dahlin Foundation.

1 Kato N, Hoshino H, Harada F. Nucleotide sequence of 4.5S RNA (C8 or hY5) from HeLa cells. Biochem. Biophys Res Commun 1982;108:363-70.

2 Hendrick JP, Wolin SL, Rinke J, Lerner MR, Steitz JA. Ro small cytoplasmic ribonucleoproteins are a subclass of La ribonucleoproteins:further characterization of the Ro and La small ribonucleoproteins from uninfected cells mamLa small ribonucleoproteins from uninfected

3 Wolin SL, Steitz JA. The Ro small cytoplasmic ribonucleoprotein: identification of the antigenic protein and its binding site on the Ro RNAs. Proc Natl Acad Sc USA 1984;81:1996-2000.

4 Stefano E. Purified lupus antigen La recognizes an oligouridylate stretch common to the 3 'termini of RNA polymerase III transcripts. Cell 1984;36:145-54.

5 Gottlieb E, Steitz JA. The RNA binding protein La influences both the accuracy and efficiency of RNA polymerase III in vitro. EMBO J 1989;8:851-61

6 Gottlieb E, Steitz JA. Function of the mammalian La protein: Evidence for its action in transcription termination by RNA polymerase III. EMBO J 1989;8:841-50.

7 O'Brien CA, Harley JB. A subset of hY RNAs is associated with erythrocyte Ro ribonucleoprotein. EMBO J 1990;9: with erythry

8 Ben-Chetrit E, Chan EKL, Sullivan KF, Tan EM. A 52-kD protein is a novel component of the SS-A/Ro antigenic particle. J Exp Med 1988;167:1560-71.

9 Slobbe RL, Prujin GJM, Damen WGM, Van der Kemp JWCM, Van Venrooij WJ. Detection and occurrence of the $60-$ and $52-\mathrm{kD}$ Ro (SS-A) antigens and of autoantibodies against these proteins. Clin Exp Immunol 1991;86:99105.

10 Ben-Chetrit E, Gandy BJ, Tan EM, Sullivan KF. Isolation and characterization of a cDNA clone encoding the $60-\mathrm{kD}$ component of human SS-A/Ro ribonucleoprotein autoantigen. J Clin Invest 1989;83:1284-92.

11 Deutscher S, Harley JB, Keene JD. Molecular analysis of the human Ro ribonucleoprotein. Proc. Natl Acad Sci USA human Ro ribonu

12 Chan EKL, Hamel JC, Buyon JP, Tan EM. Molecular definition and sequence motifs of the $52-\mathrm{kD}$ component of human SS-A/Ro autoantigen. J Clin Invest 1991;87:68-76.

13 Itoh K, Itoh Y, Frank MB. Protein heterogeneity in the human Ro/SSA ribonucleoproteins. The 52- and $60-\mathrm{kD}$ Ro/SSA autoantigens are encoded by separate genes. J Clin Invest 1991;87:177-86.

14 Peek R, Pruijn GJM, van Venrooij WJ. Epitope specificity determines the ability of anti-Ro52 autoantigbodies to precipitate Ro ribonucleoprotein particles. J Immunol 1994; 153:4321-9.

15 Boire G, Gendron M, Monast N, Bastin B, Ménard HA. Purification of antigenically intact Ro ribonucleoproteins; biochemical and immunological evidence that the $52-\mathrm{kD}$ protein is not a Ro protein. Clin Exp Immunol 1995;100: 489-98.

16 Peek R, Pruijn GJM, Vanderkemp AJW, van Venrooij WJ. Subcellular distribution of Ro ribonucleoprotein complexes and their constituents. J Cell Sci 1993;106:929-35.

17 Simons FHM, Pruijn GJM, van Venrooij WJ. Analysis of the intracellular localization and assembly of Ro ribonucleoprotein particles by microinjection into the Xenopus laevis oocytes. J Cell Biol 1994;125:981-8.

18 Kelekar A, Saitta MR, Keene JD. Molecular composition of Ro small ribonucleoprotein complexes in human cells intracellular localization of the $60-$ and $52-\mathrm{kD}$ proteins. Clin Invest 1994;93:1637-44.

19 Sontheimer RD. Subacute cutaneous lupus erythematosus: a decade's perspective. Med Clin North Am 1989;73: 1073-90.

20 McCauliffe DP, Lux FA, Lieu TS, Sanz I, Hanke J, Newkirk MM, et al. Ro/SS-A and the pathogenic significance of its MM, et al. Ro/SS-A and the pathogenic
antibodies. J Autoimmun 1989;2:375-81.

21 Horsfall AC, Rose LM, Maini RN. Autoantibody synthesis in salivary glands of Sjögren's syndrome patients. J Autoimmun 1989;2:251-60. 
22 Halse A, Wahren-Herlenius M, Jonsson R. Ro/SS-A- and $\mathrm{La} / \mathrm{SS}-\mathrm{B}-$ reactive B lymphocytes in peripheral blood of patients with Sjogren's syndrome. Clin Exp Immuno 1999;115:208-13. Clin Exp Immunol 1999;115:208-13.

23 Tengner P, Halse AK, Haga HJ, Jonsson R, WahrenHerlenius $M$. Detection of anti-Ro/SSA and anti-La/SSB autoantibody-producing cells in salivary glands from patients with Sjogren's syndrome. Arthritis Rheum 1998; 41:2238-48.

24 Gumpel JM, Hobbs JR. Serum immune globulins in Sjogren's syndrome. Ann Rheum Dis 1970;29:681-3.

25 Whaley K, Webb J, McAvoy BA, Hughes GR, Lee P, MacSween RN, et al. Sjogren's syndrome. 2. Clinical associations and immunological phenomena. Q J Med 1973;42: tions an

26 Conley ME, Koopman WJ. Serum IgA1 and IgA2 in normal adults and patients with systemic lupus erythematosus and hepatic disease. Clin Immunol Immunopathol 1983;26: 390-7

27 Vitali C, Bombardieri S, Moutsopoulos HM, Balestrieri G, Bencivelli W, Bernstein RM, et al. Preliminary criteria fo the classification of Sjögren's syndrome - results of a prospective concerted action supported by the European Community. Arthritis Rheum 1993;36:340-7.

28 Tan EM, Cohen AS, Fries JF, Masi AT, McShane DJ, Rothfield NF, et al. The 1982 revised criteria for the classification of systemic lupus erythematosus. Arthritis Rheum 1982;25:1271-7.

29 Pourmand N, Pettersson I. The $\mathrm{Zn} 2+$ binding domain of the human Ro $52 \mathrm{kDa}$ protein is a target for conformationdependent autoantibodies. J Autoimmun 1998;11:11-17.

30 Wahren M, Ruden U, Andersson B, Ringertz NR, Pettersson I. Identification of antigenic regions of the human Ro $60 \mathrm{kDa}$ protein using recombinant antigen and synthetic peptides. J Autoimmun 1992;5:319-32.

31 Nyman U, Ringertz NR, Pettersson I. Demonstration of an aminoterminal La epitope recognized by human anti-La sera. Immunol Lett 1989;22:65-72.

32 Akerstrom B, Bjorck L. A physicochemical study of protein $\mathrm{G}$, a molecule with unique immunoglobulin G-binding properties. J Biol Chem 1986;261:10240-7.

33 Bruggemann $M$, Williams GT, Bindon CI, Clark MR, Walker MR, Jefferis $\mathrm{R}$, et al. Comparison of the effector functions of human imm et al Complins using a matched set functions of human immunoglobulins using a matched

34 Michaelsen TE, Aase A, Westby C, Sandlie I. Enhancement of complement activation and cytolysis of human IgG3 by of complement activation and cytolysis of human IgG3 by
deletion of hinge exons. Scand I Immunol 1990;32:517-28.
35 Wahren M, Ringertz NR, Pettersson I. IgM and IgG subclass distribution of human anti-Ro/SSA $60 \mathrm{kD}$ autoantibodies. Scand J Immunol 1994;39:179-83.

36 Blange I, Ringertz NR, Pettersson I. Identification of antigenic regions of the human $52 \mathrm{kD} \mathrm{Ro/SS}$-A protein recognised by patient sera. J Autoimmun 1994;7:263-74.

37 Wehmeyer A, Das PK, Swaak T, Gebhart W, Kijlstra A. Sjogren syndrome: comparative studies in local ocular and serum immunoglobulin concentrations with specia reference to secretory IgA. Int Ophthalmol 1991;15:14751.

38 Chretien P, Soulie E, Johanet C, Abuaf N. Comparisons of double immunodiffusion, ELISA, western blot and CAPE blot for the detection of anti-SSA antibody: study of blot for the detection of anti-SSA antibody: study of
anti-SSA prevalence in systemic lupus erythematosus. J Autoimmun 1994;7:379-88.

39 Meilof JF, Bantjes I, De Jong J, Van Dam AP, Smeenk RJ The detection of anti-Ro/SS-A and anti-La/SS-B antibodies. A comparison of counterimmunoelectro- phoresis with immunoblot, ELISA, and RNA- precipitation assays. J Immunol Methods 1990;133:215-26.

40 Mestecky J, McGhee JR. Immunoglobulin A (IgA): molecular and cellular interactions involved in IgA biosynthesis and immune response. Adv Immunol 1987;40:153-245.

41 Russell MW, Mansa B. Complement-fixing properties of human IgA antibodies. Alternative pathway complement activation by plastic-bound, but not specific antigenbound, IgA. Scand J Immunol 1989;30:175-83.

42 Bogers WM, Stad RK, van Es LA, Daha MR. Immunoglobulin A: interaction with complement, phagocytic cells and endothelial cells. Complement and Inflammation 1991;8:347-58.

43 Hall RP, Stachura I, Cason J, Whiteside TL, Lawley TJ. IgA-containing circulating immune complexes in patients with IgA nephropathy. Am J Med 1983;74:56-63.

44 Gunnarsson I, Ronnelid J, Lundberg I, Jacobson SH. Occurrence of anti-C1q antibodies in IgA nephropathy. Nephrol Dial Transplant 1997;12:2263-8.

45 Zoli A, Altomonte L, Caricchio R, Galossi A, Mirone L, Scuderi F, et al. Rheumatoid factor in patients with systemic lupus erythematosus. Clin Rheumatol 1996;15: 312-13.

46 Elkon KB, Gharavi AE, Hughes GR, Moutsoupoulos HM. Autoantibodies in the sicca syndrome (primary Sjogren's syndrome). Ann Rheum Dis 1984;43:243-5. 